\title{
A Brief Analysis of the Influence of Internet Finance on Traditional Commercial Banks under the Background of "One Belt One Road"
}

\author{
Wanying Rao \\ School of Finance \\ Yunnan University of Finance and Economics \\ Kunming, China \\ 258376620@qq.com
}

\author{
Meng Sun* \\ Business School \\ Yunnan University of Finance and Economics \\ Kunming, China \\ 493435756@qq.com
}

\begin{abstract}
This article analyzes the development of China's Internet finance and the status quo of traditional commercial banks and the impact of Internet finance on traditional commercial banks under the background of "One Belt One Road" strategy, in order to better grasp the historical opportunities and promote the innovation of commercial banks, this will drive the emerging financial development model and give greater play to the historical role of the "One Belt One Road" strategy.
\end{abstract}

Keywords-“One Belt One Road"; internet finance; commercial Bank

\section{INTRODUCTION}

In September and October of 2013, the Chinese President Xi Jinping proposed cooperation initiatives for the "New Silk Road Economic Belt" and "21st Century Maritime Silk Road" respectively, aiming to strengthen economic cooperation and mutual benefit and win-win cooperation among the countries along the route in order to achieve the common goal of a healthy and stable development of all countries' economies, it also promoted cultural exchanges and peaceful development in different countries. China's "One Belt One Road" is an inclusive project that is pregnant to profound changes for International Political Economy but also for Chinese Political Economy [1].

In the 21st century, the Internet has influenced the development of the traditional financial industry with invisible forces [2]. Internet finance is an emerging financial model. Its development not only impacts the scope of business operations of traditional commercial banks, but also affects the operating model of commercial banks [3].As a typical representative of innovation in the financial industry, the rapid growth of Internet finance has created a certain impact on the assets, liabilities and intermediary businesses of traditional commercial banks. Based on the "One Belt One Road" strategy, there are new opportunities for Internet finance, and the development of traditional commercial banks are facing new challenges.

Due to the rapid development of Internet finance in recent years, many scholars have published their own research findings and opinions based on the development of the Internet. Liu analyzed the necessity of financial supervision based on the current development of financial innovation [4]. Huang carried out that the e-commerce financing in Internet finance has the biggest impact on economy and finance [5]. Peng put forward that internet finance has operator risks, legal compliance risks, operating technology risks, market liquidity risks, capital security risks, and monetary policy risks [6]. Zhou et al. analyzed that anonymity and virtual of Internet finance can hide the information required by regulation. Therefore, it is necessary to innovation Internet financial supervision methods [7].

The rapid development of Internet finance has had a huge impact on China's traditional commercial banks. Hao et al. explored the impulse and influence of internet finance on traditional commercial banks in both short-term and long-term terms [8]. Zhou et al. that third-party payment has become an important part of the financial services industry in the new era. It has also become a core pillar of the rapid development of China's Internet and economic related industries [9].Yang analyzed the impact of Internet finance on the three aspects of commercial bank operations, profitability and business model [10]. Zhou et al. believe that the impact of internet finance through its asset business, liability business, and intermediary business on banks will lead to the trend of financial disintermediation and ultimately threaten the commercial bank's operating performance and business model [11]. Zheng through retail and commercial banking business model similarity comparison research, as well as the "Internet + retail " effect of traditional retail perspective to analyze the financial impact of the Internet on the commercial banks [12]

Based on the above literature review and the significance of the "One Belt One Road" Strategy, this paper is organized as follows: First of all, this article will analyze the development of Internet finance in recent years. Subsequently, this article will briefly analyze the new opportunities brought by the "One Belt One Road" to the development of China's Internet. Further, this article will analyze how the development of the Internet caters to the requirements of the "One Belt One Road" strategy. And then, this article will explain the impact of the

*Corresponding author 
development of internet finance on traditional commercial banks from three aspects. Then, the article will analyze the transformation strategy of commercial banks in the context of "One Belt One Road" from three perspectives, finally summarize the full text and give conclusions.

\section{THE “BELT AND ROAD” STRATRGY BRINGS NEW OPPORTUNITIES FOR THE DEVELOPMENT OF INTERNET FINANCE}

Since the beginning of this century, the development of information technology represented by network technology, automation and intelligence, and mobile communication technology has shown strong momentum, showing a high degree of integration, wide application, and rapid development [13]. Under this situation, emerging Internet information technologies such as social networking, cloud computing, big data, and mobile Internet have begun to gradually infiltrate into the business sector, subtly changing people's lifestyles and behaviors, and stimulating a new business model-Internet finance. Crowdfunding, $\mathrm{p} 2 \mathrm{p}$ online lending, third-party payment, and big data finance are the main operating modes of internet finance [14]. In recent years, internet wealth management products have also risen rapidly. In June 2013, Taobao and Tianhong Fund launched Yu'e Bao. Yu'e Bao has exceeded 400 billion yuan, triggering extensive discussions among people from all walks of life.

Under the "One Belt One Road" background, the development of Internet finance will face new opportunities. Firstly, the interconnection of the "One Belt One Road" strategic plan will strengthen the financial integration and currency integration of the countries and regions along the route, the construction of infrastructure will help companies to go out further, thus furthering the process of RMB internationalization, and stepping forward to lay a solid foundation for the integration of non-economic and financial sectors in Europe and Asia. Secondly, the implementation of the "One Belt One Road" strategy will not only promote the development of domestic Internet finance to a great extent, but also have significant implications for the development of Internet finance in countries and regions related to the "One Belt One Road" strategy. Finally, the "One Belt One Road" strategy is also a historic development opportunity for crossborder e-commerce, making China's cross-border e-commerce in a more international leading position.

\section{THE DEVELOPMENT OF INTERNET FINANCE CATERS TO} THE STRATEGIC NEEDS OF THE "BELT AND ROAD INITIATIVE"

The "One Belt One Road" strategy has many projects at the current stage and has huge capital requirements. Active implementation of policies such as the establishment of an Asian Infrastructure Investment Bank (AIIB), the addition of overseas banks of state-owned banks, and the establishment of a silk road fund all require the participation of Internet finance. The Internet finance $\mathrm{P} 2 \mathrm{P}$ online lending and crowdfunding platform will facilitate the financing of small to medium-sized enterprises in the countries along the route [15]. Its operational efficiency has brought the gospel to the countries along the route and it is also an important part of promoting the development of China's national economy. The development of Internet finance and new types of Internet financial products cater to the needs of the "One Belt One Road" strategy. Internet finance will play an important role in the "One Belt One Road" strategy.

\section{THE IMPACT OF INTERNET FINANCIAL DEVELOPMENT ON TRADITIONAL COMMERCIAL BANKS}

\section{A. Impact on Payment Function of Traditional Commercial Banks}

In terms of fees. From 2010 to now, Internet finance accounts for $80 \%$ of the payment market share, which has surpassed the total online payment of banks and UnionPay. As shown in Figure 1, from 2009 to 2017, the number of sales in "Double 11" increased from 50 million to 168.2 billion, with a growth rate of $3364 \%$. This record-breaking number makes Alipay continue to expand as the leading mobile payment company in the world. People use Alipay's credit card repayment function to bypass other bank card transfer fees. Internet payment will further affect bank fee income in the future, because most of the financial services that are currently handled through the Internet in the market are young groups. Young people, as the main force in the future, cannot be ignored.

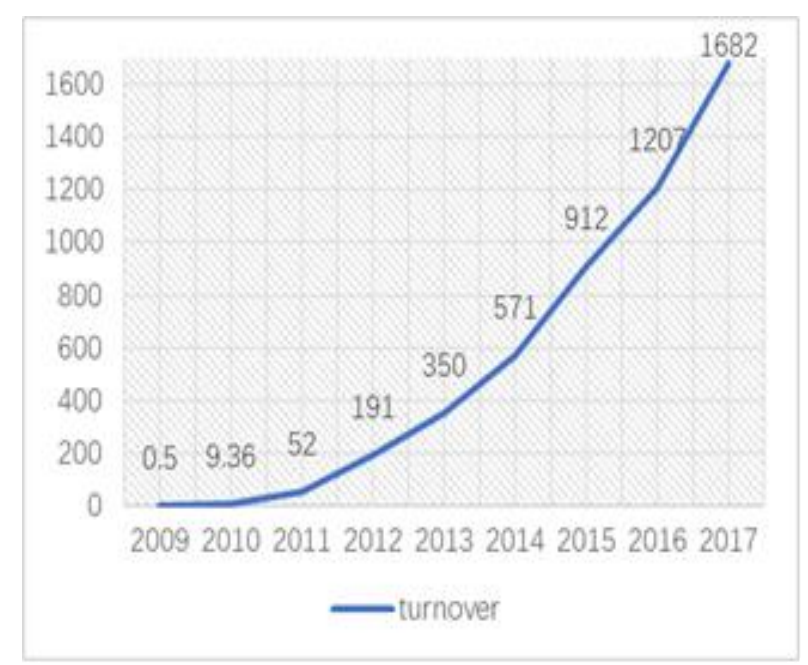

Fig. 1. The number of sales in "Double 11" over the years Multinational corporations use employment structure ratio

In terms of settlement function. The current mass consumption, entertainment, leisure and work methods tend to be more networked and pay more attention to the timeliness of payment and settlement. Internet finance is widely involved in various payment services with the aid of online platforms, mobile technologies, etc., and meets the payment needs of various customer groups with a personalized and diversified product portfolio. With the rise of internet finance, people's lives have become increasingly diversified and virtualized. The payment and settlement of traditional commercial banks have been unable to meet the needs of the development of the times. Therefore, major banks are also constantly innovating in the field of payment and settlement. 


\section{B. Impact on Financial Functions of Traditional Commercial Banks}

In terms of deposit. Internet finance is highly secure and can be considered almost as a risk-free or very low-risk investment product. The Internet exclusive fund is superior to the traditional fund form, it competes fiercely with traditional commercial bank deposits in the capital market.

In terms of insurance and fund agency business. As shown in Figure 2, the average rates of Agricultural Bank of China $(\mathrm{ABC})$ and China Merchants Bank (CMB) sales in the year of 2017 were approximately $4.11 \%$ and $5.97 \%$ respectively, and the agency ratios of the funds were approximately $1.2 \%$ and $1.5 \%$, respectively. If a third-party Internet platform is used for agency sales, commercial banks can only obtain online fee processing fees, which is about $0.5 \%$. Internet finance will effectively reduce the revenues from the channels of bank insurance and fund agency, resulting in a reduction in the expenses of traditional commercial bank insurance and fund agency fees.

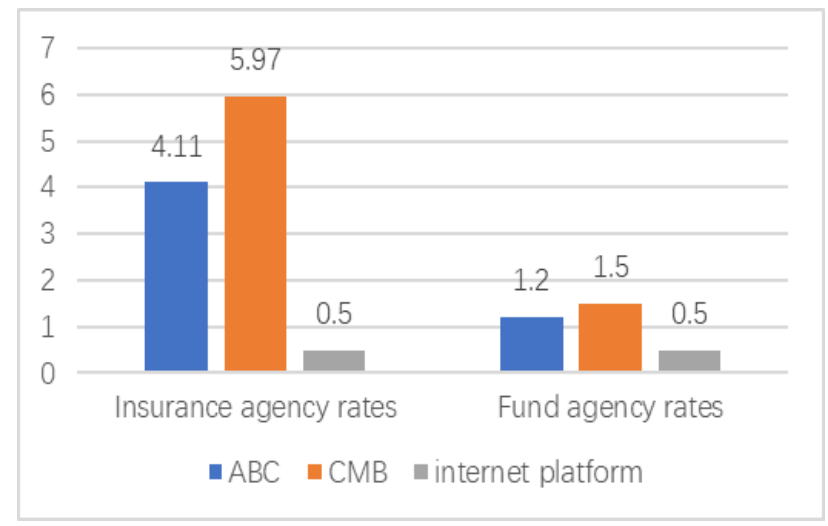

Unit: percentage

Fig. 2. List of rates

\section{Impact on the Operational Functions of Traditional Commercial Banks}

In terms of commercial bank status. The rapid development of Internet finance has a great impact on the core status of traditional commercial banks. Commercial banks have always been the core of the financial industry. With the rapid rise of Internet finance, customers have more choices in the use of funds, and various investment channels, which greatly impact the traditional sources of funds for commercial banks.

Commercial bank operation scale. The various products of internet finance have led to a continuous tightening of the scale of banking operations. For example, Yu'e Bao that Tianhong Fund and Alipay jointly launched has had a huge impact on traditional commercial bank deposits. As one of the money funds, Yu'e Bao's annualized yield exceeds 5\%, and can be transferred in and out at any time. It provides a variety of services such as credit card repayment and online payment, which can fully meet young people's daily needs. Funding needs.
V. THE TRANSFORMATION STRATEgy OF COMMERCIAL BANK UNDER THE BACKGROUND OF "ONE BELT ONE ROAD" STRATEGY

\section{A. Paying Attention to the Opportunity Brought by the "One Belt One Road" Strategy}

The "One Belt One Road" is a national strategy and an international policy. The traditional commercial banks should be unified with the "One Belt One Road" construction, make full use of strategic resources and power, and help the traditional banking industry "go out". While improving the financial level and service level of the banking industry, innovative financial products and services have laid a solid foundation for the transition from the traditional banking industry to the new banking industry.

\section{B. Building an E-commerce Platform Based on the Internet}

With the development of science and technology, information data accumulates through the big data in the internet finance, and provides customers with personalized analysis and design of corresponding financial services, thus constructing a scientific development model. Traditional commercial banks need to develop their own data, attach importance to big data information, strengthen the processing capacity of large amounts of information, build their own ecommerce platform, and cooperate with Internet companies to combine online and offline businesses, which will not only reduce counterpoints. The operating pressures at the same time provide customers with more convenient financial services and enhance the contact and communication with customers.

\section{Innovative Commercial Bank Management Mechanism}

The "One Belt One Road" covers many countries and regions. Due to the economic and cultural differences between countries, commercial banks must establish new management mechanisms and management systems in a targeted "Belt and Road" strategy. Commercial banks must support the regional economy, develop distinctive services, support the "One Belt One Road" strategy in action, and adapt the internationalization environment brought by the Belt and Road initiative through innovative management mechanisms so as to make full use of markets and resources.

\section{CONClusion}

Internet finance based on information technology is developing rapidly, bringing great changes to people's lives. At the same time, the implementation of the "One Belt One Road" strategy not only brought better opportunities for Internet finance, but also accelerated the transformation of traditional commercial banks. The "One Belt One Road" strategy is a new measure for China's economic development. It should take the "One Belt One Road" as a good opportunity for the transformation of traditional commercial banks, and continuously improve the service quality and development potential of the banking industry, in order to better adapt to the development trend of Internet finance and meet challenges. 


\section{ACKNOWLEDGMENT}

This work was supported by the Natural Science Foundation of China [No. 71561026]; and Applied Basic Research Programs of Science and Technology Commission of Yunnan Province [No. 2017FB102].

\section{REFERENCES}

[1] Nalbantoglu C, "One Belt One Road Initiative: New route on China's change of course to growth," Open Journal of Social Sciences, 2017, pp. 87-99.

[2] Zhou W, "Dynamic and asymmetric contagion reactions of financial markets during the last subprime crisis," Computational Economics, 2017, pp. 207-230.

[3] Yang S, "The influence of internet finance on traditional commercial banks and countermeasures," Value Engineering, 2018.

[4] Liu N L, "Financial innovation and financial regulation: Thinking on the development of internet finance," Journal of Wuhan University of Technology, 2015.

[5] Huang H, "Research of the internet finance with the core as E-commerce platform," Shanghai Finance, 2013.

[6] Peng W, "A study of the risks and regulation of Chinese internet finance," Finance Forum, 2014.
[7] Zhou W, and Xu Z, "Generalized asymmetric linguistic term set and its application to qualitative decision making involving risk appetites," European Journal of Operational Research, 2016, pp. 610-621.

[8] Hao S, and Chen H, "The short-term impulse and far-reaching influence of internet finance on traditional commercial banks," Journal of Shanghai Administration Institute, 2015.

[9] Zhou W, and Xu Z, "Expected hesitant VaR for tail decision making under probabilistic hesitant fuzzy environment," Applied Soft Computing, 2017, pp. 297-311.

[10] Yang S, "The influence of internet finance on traditional commercial banks and countermeasures," Value Engineering, 2018.

[11] Zhou W, and Xu Z, "Group consistency and group decision making under uncertain probabilistic hesitant fuzzy preference environment," Information Sciences, 2017, pp. 276-288.

[12] Zheng Z, "The influence of internet finance of commercial banksBased on the perspective of the influence of "internet + " on the retail industry," Finance \& Economics, 2015.

[13] Zhou W, and Xu Z, "Probability calculation and element optimization of probabilistic hesitant fuzzy preference relations based on expected consistency," IEEE Transactions on Fuzzy Systems, 2018, pp. 13671378.

[14] Zhou W, and Xu Z, "Portfolio selection and risk investment under the hesitant fuzzy environment," Knowledge-Based Systems, 2018. pp. 2131.

[15] Zhou W, and He J, "Generalized GM $(1,1)$ model and its application in forecasting of fuel production, Applied Mathematical Modelling, 2013,pp.6234-6243. 